University of Nebraska - Lincoln

DigitalCommons@University of Nebraska - Lincoln

2008

\title{
A New Species of Schizomyia (Diptera: Cecidomyiidae), a Pest of Fernaldia pandurata (Apocynaceae) in Central America
}

\section{Raymond Gagne}

Systematic Entomology Laboratory, PSI, Agricultural Research Service, USDA, c/o U. S. National Museum NHB 168, P.O. Box 37012, Washington, DC 20013-7012, USA, raymond.gagne@ars.usda.gov

Rafael Menjivar

Follow this and additional works at: https://digitalcommons.unl.edu/systentomologyusda

Part of the Entomology Commons

Gagne, Raymond and Menjivar, Rafael, "A New Species of Schizomyia (Diptera: Cecidomyiidae), a Pest of Fernaldia pandurata (Apocynaceae) in Central America" (2008). USDA Systematic Entomology Laboratory. 24.

https://digitalcommons.unl.edu/systentomologyusda/24

This Article is brought to you for free and open access by the Entomology Collections, Miscellaneous at DigitalCommons@University of Nebraska - Lincoln. It has been accepted for inclusion in USDA Systematic Entomology Laboratory by an authorized administrator of DigitalCommons@University of Nebraska - Lincoln. 


\title{
A NEW SPECIES OF SCHIZOMYIA (DIPTERA: CECIDOMYIIDAE), A PEST OF FERNALDIA PANDURATA (APOCYNACEAE) IN CENTRAL AMERICA
}

\author{
Raymond J. Gagné and Rafael Menjivar
}

(RJG) Systematic Entomology Laboratory, PSI, Agricultural Research Service, USDA, c/o U. S. National Museum NHB 168, P.O. Box 37012, Washington, DC 200137012, U.S.A. (e-mail: rgagne@sel.barc.usda.gov); (RM) P.O. Box 3110, Depto. Protección Vegetal, Facultad de Ciencias Agronómicas, Final 25, Av. Norte, Ciudad Universitaria, San Salvador, El Salvador (e-mail: rafaelmenjivarrosa@yahoo.com)

Abstract.-A new species of gall midge, Schizomyia loroco Gagné (Diptera: Cecidomyiidae), is described from loroco, Fernaldia pandurata (A. DC.) Woodson (Apocynaceae), from El Salvador. Females lay eggs in flower buds that then produce characteristic galls. The new species is described, illustrated, and compared to its congeners.

Key Words: loroco, flower gall, gall midges, Neotropical

Fernaldia pandurata (A.DC.) Woodson, or loroco, is a tall, herbaceous vine, endemic to lowland wet forest of Central America and southern Mexico. Flower buds are commonly used in Salvadoran cooking and to a lesser extent that of other Central American countries. Until recently the plant was grown on small farms and home gardens in El Salvador, but is now being extensively bred and developed as a commercial crop for domestic consumption and export to the United States and Canada. A more ancient common name for the plant is "quilite," still used instead of loroco in some parts of El Salvador. The plant normally flowers in the wet season from June to October, but with irrigation the season can be extended somewhat (Anonymous 2002).

Flowers of this plant are host to a gall midge that has several generations during at least the main growing season of the plant. Eggs are laid among scales of flower buds that soon after turn into characteristic galls (Fig. 1). Two to seven orange larvae can be found in each gall in separate elongate chambers. Fullgrown larvae drop to the soil and spin a cocoon in which they pupate. The infested buds rot and fall to the ground after larval drop. Since at least 1965 in the experience of one of us (RJG), galls in shipments of loroco from El Salvador have been intercepted by APHIS inspectors at United States ports-of-entry and sent to the Systematic Entomology Laboratory (SEL) for identification where they were identified as Schizomyia sp. or Schizomyia n. sp. Since 1993, when computerized records were begun of SEL identifications, to the present, larvae from galls were submitted to the SEL 57 times, once each from Costa Rica, Guatemala, and Honduras, the remainder from El Salvador (unpublished). One of us (RM) succeeded after several years of attempts to rear adults, a task hampered by the high level of parasitization by micro-Hymenoptera. Adults 

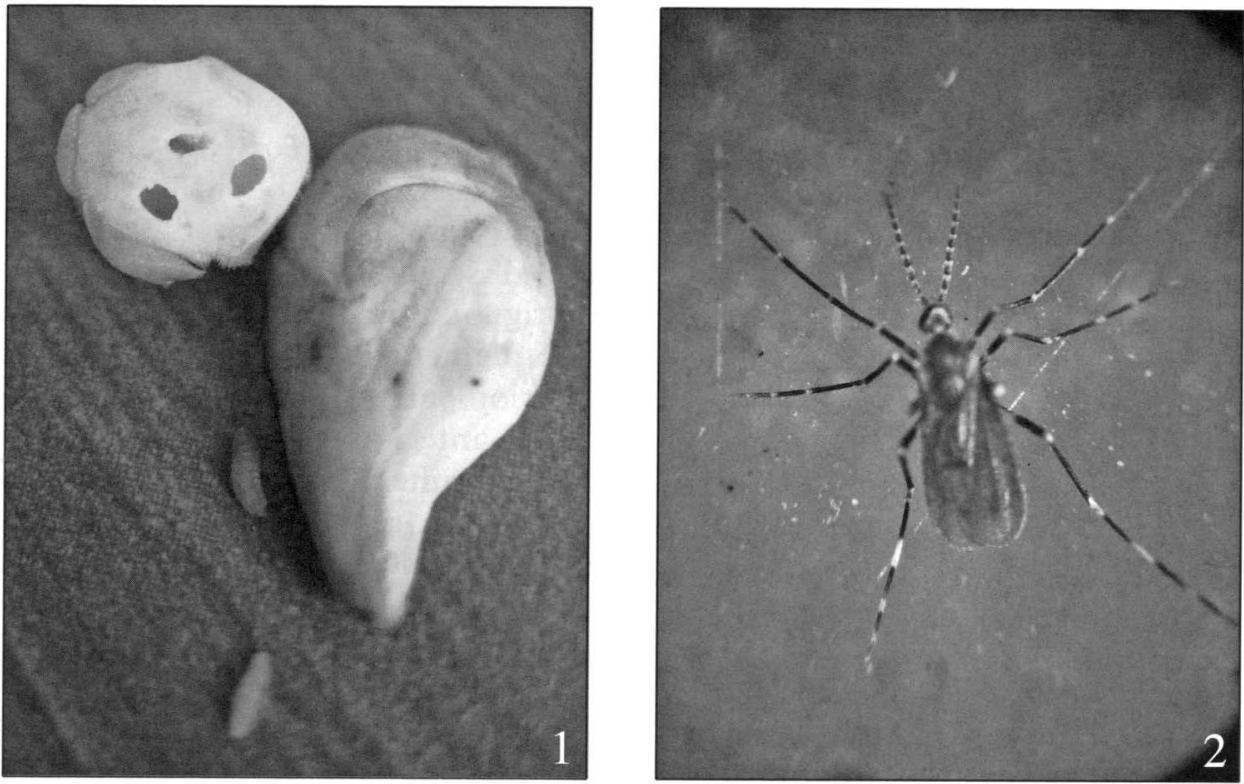

Figs. 1-2. 1, Deformed flower buds of loroco, one cut open to show larval chambers, the freed larvae crawling away. 2, Adult female Schizomyia loroco.

are confirmed to be a new species of Schizomyia and are described here.

\section{Materials and Methods}

Full-grown larvae leaving galls were collected and kept in plastic containers to obtain pupae and adults. Specimens of immature stages and adults were preserved in $70 \%$ isopropyl alcohol and sent to the Systematic Entomology Laboratory for identification. Some samples were mounted on microscope slides using the method outlined in Gagné (1989, 1994). Some pupae and larvae were dried and placed on stubs for scanning electron microscope study. Terminology for adult morphology follows usage in McAlpine et al. (1981) and for larval morphology that in Gagné (1989). Specimens and information on the life cycle were obtained by RM. The taxonomic investigation in this paper was the responsibility of RJG.

\section{Diagnosis of SchIZOMYIA}

Schizomyia (Cecidomyiinae: Asphondyliini: Schizomyiina) is a cosmopolitan genus of 49 described species (Gagné 2004). The 43 species for which the host is known come from 23 families of plants (Gagné 2004, Maia \& Fernandes 2005). Fabaceae host eight species, Vitaceae five, the remaining families host one to three species each, and only Schizomyia cryptostegiae Gagné from Madagascar is recorded for more than one genus within a family. The new species is the first record of Schizomyia from Apocynaceae. Schizomyia is distinguished from other cecidomyiids by the combination of the following features: adults with foursegmented palpus; male flagellomeres (Fig. 3) cylindrical with short necks and anastomozing, raised circumfila; female flagellomeres (Fig. 4) cylindrical with short necks and progressively shorter from antennal base to apex, the last two flagellomeres abruptly so, with appressed circumfila, basal circumfilum of each flagellomere deeply arched; first tarsomere without spur (except with spur on the three species from Vitaceae); tarsal claws hooked and with long empodia (Fig. 6) or falcate with short 
empodia (Fig. 5); gonocoxite produced posteroventrally and with proximomedial, setose lobe; gonostylus with discrete denticles (Figs. 10-11); ovipositor distal half elongate, needleform, flexible, with greatly reduced cerci (Figs. 7-8); third instar with 6 lateral papillae in two triplets on each side of the spatula (Fig. 13), eighth abdominal segment with a mediodorsal lobe on the posterior margin, terminal segment with four pairs of terminal papillae, three of them setiform, one corniform (Figs. 14-16, 20). In addition the larvae share the feature of leaving the gall to pupate in the soil.

\section{Schizomyia loroco Gagné, new species}

(Figs. 2-5, 7-14, 17-20)

Adult (Fig. 2).-Color: Scape and pedicel light brown; flagellomeres each fuscous on basal three-fourths, white beyond; thoracic sclerites brown; wing covered with black scales, membrane fuscous; legs covered with mostly black scales but white on middle tenth of femur, and adjacent to all leg joints; legs dull white when scales rubbed off; abdomen covered with dark brown scales, beneath scales tergites and sternites brown and intersegmental areas orange.

Head: Eyes large, connate, eye bridge about 10 facets long; facets hexagonal, closely adjacent throughout. Occiput without dorsal protuberance. Frons with 8-12 setae per side. Antenna: male third flagellomere as in Fig. 3; female third flagellomere as in Fig. 4. Labella hemispherical in frontal view, each with 8-10 lateral setae.

Thorax: Wing length, male 1.8$2.0 \mathrm{~mm}(\mathrm{n}=5)$, female $1.8-2.2 \mathrm{~mm}(\mathrm{n}$ $=5$ ). Acropods with claws falciform, empodia and pulvilli about $1 / 4$ length of claws (Fig. 5).

Male abdomen: First through fifth tergites entire, rectangular, each with single, uninterrupted, posterior row of setae, no lateral setae, a pair of trichoid sensilla on anterior margin, and otherwise evenly covered with scales. Sixth tergite as for fifth but additonally with several lateral setae on each side. Seventh tergite as for sixth but with only partial single row of posterior setae, many more lateral setae, both setal groups nearly contiguous. Eighth tergite membranous, not pigmented, its only vestiture the anterior pair of trichoid sensilla demarcating anterior margin. Second through sixth sternites with double row of setae posteriorly, separated from a horizontal group of setae at midlength, and with anterior pair of closely approximated trichoid sensilla. Seventh and eighth sternites similar to preceding except with more numerous setae near midlength and the anterior pair of trichoid sensilla of eighth sternite widely separated from one another. Genitalia (Figs. 10-12): cerci long with large apical setae; hypoproct narrow, apically divided into 2 lobes, each tipped with a seta; aedeagus gradually tapering from wide base to narrow, acute apex, longer than hypoproct; gonocoxite greatly produced posteroventrally, proximomedial lobe setose; gonostylus broad in dorsal view, bilaterally flattened, apical tooth covering about half of apical edge, and with short-setose apicoposterior lobe.

Female abdomen (Figs. 7-9): First through sixth tergites as for male. Seventh tergite with single, full row of posterior setae, these well separated from the numerous lateral setae. Eighth tergite with anterior pair of trichoid sensilla the only vestiture, posterior margin deeply concave on lateral third and more shallowly concave medially, the concavity accommodating pair of small dorsal lobes between tergite and ovipositor. Second through sixth sternites as in male. Seventh sternite enlarged, shieldlike, more stongly sclerotized than preceding and completely covered with setae. Ovipositor elongate, protrusible, distal half needleform, about 4.3 times 

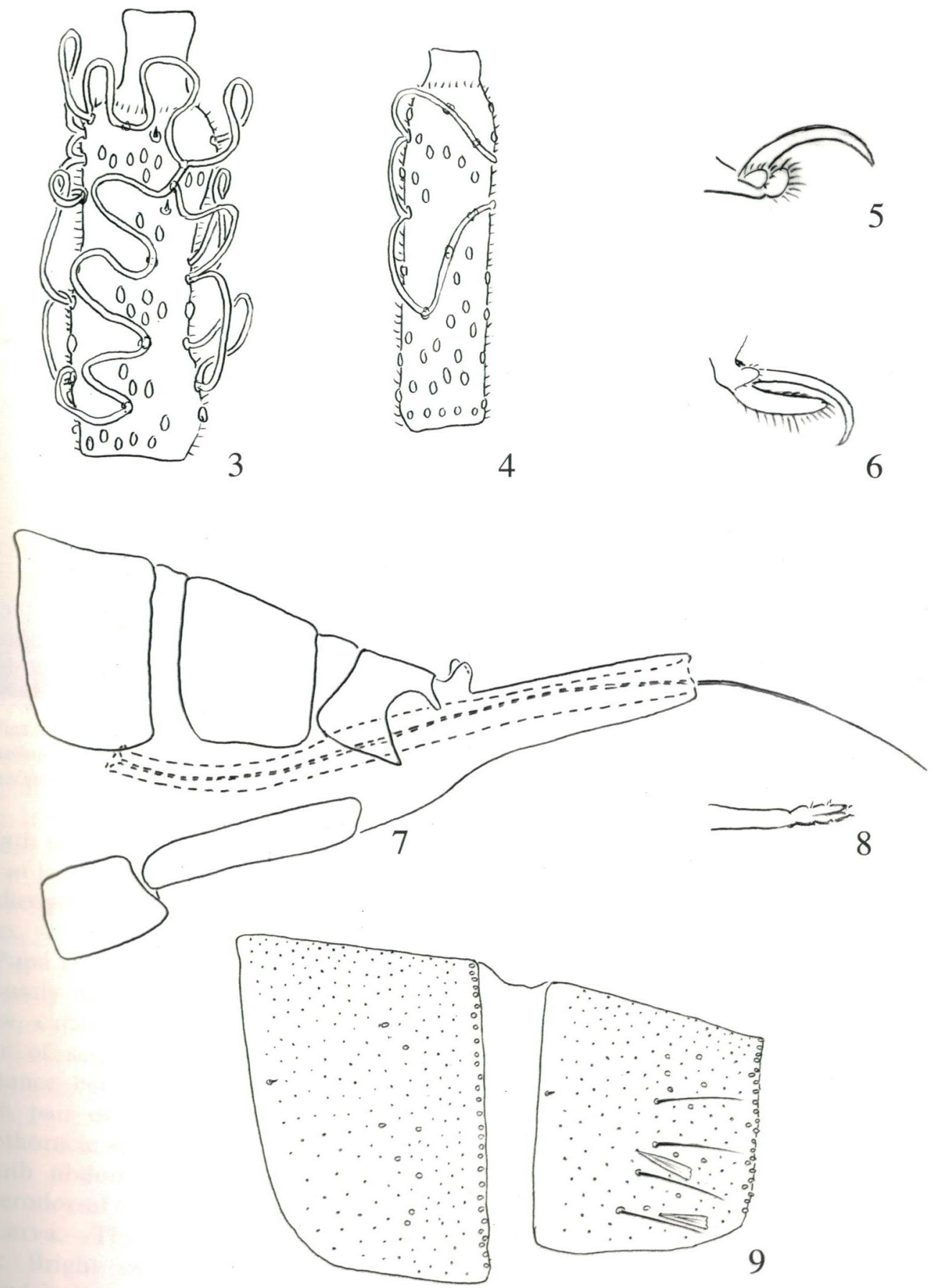

Figs. 3-9. 3-5, Schizomyia loroco. 3, Male third flagellomere. 4, Female third flagellomere. 5, Acropod. 6, S. ipomoeae, acropod. 7-9, S. loroco. 7, Female abdomen, sixth segment to cerci (lateral). 8, Detail of female cerci (dorsoventral). 9, Detail of female sixth and seventh tergites. 

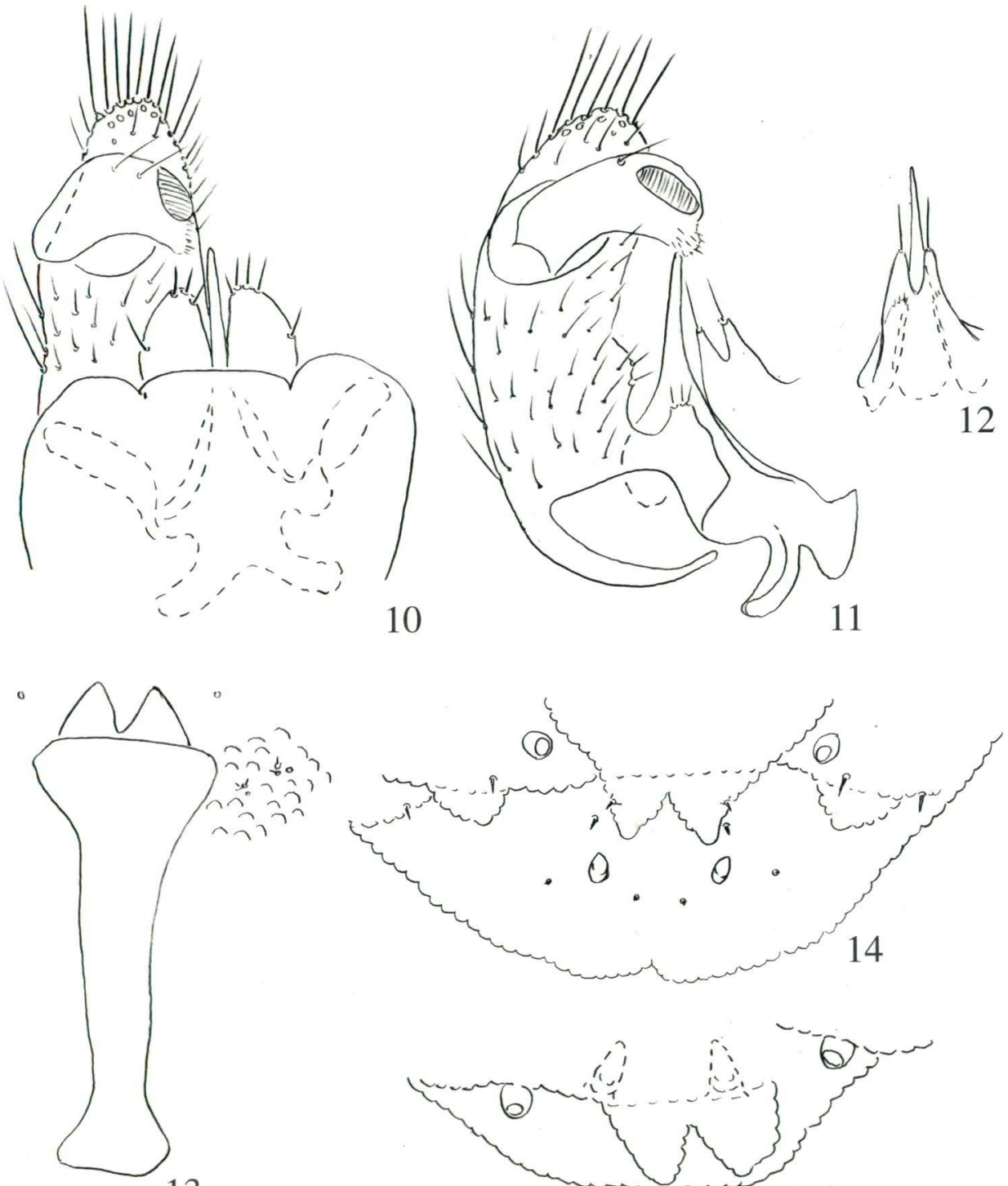

13
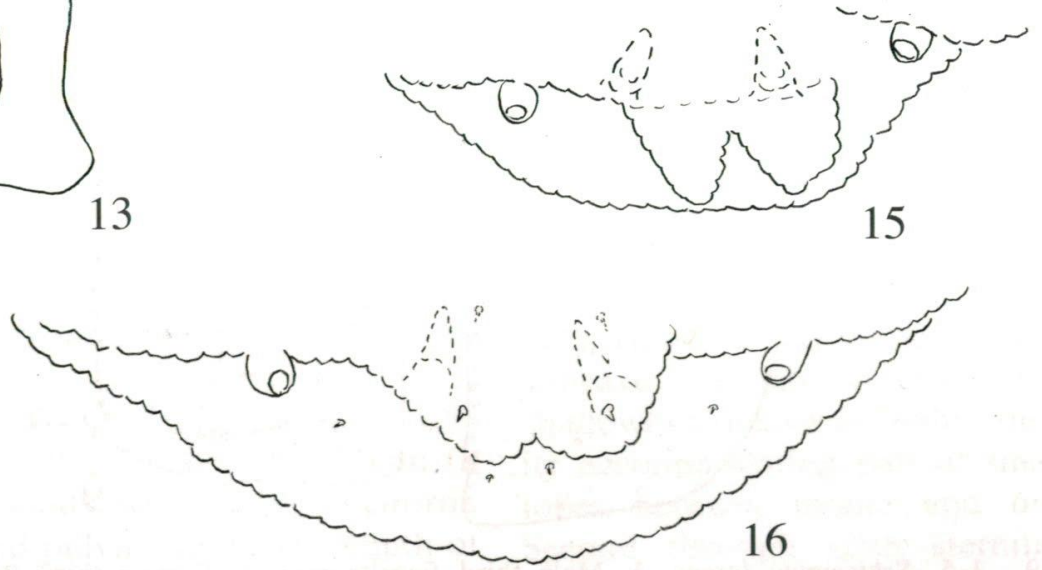

Figs. 10-16. 10-14, Schizomyia loroco. 10, Male genitalia, one gonopod removed (dorsal). 11, Same, with cerci also removed (dorsolateral). 12, Hypoproct, gonocoxal lobes, and aedeagus (dorsal). 13, Larval spatula and adjacent papillae. 14, Larval eighth and terminal segments (dorsal). 15, S. impatientis, larval eighth and terminal segments (dorsal; details not visible on preparation). 16, S. eupatoriflorae, larval eighth and terminal segments. 

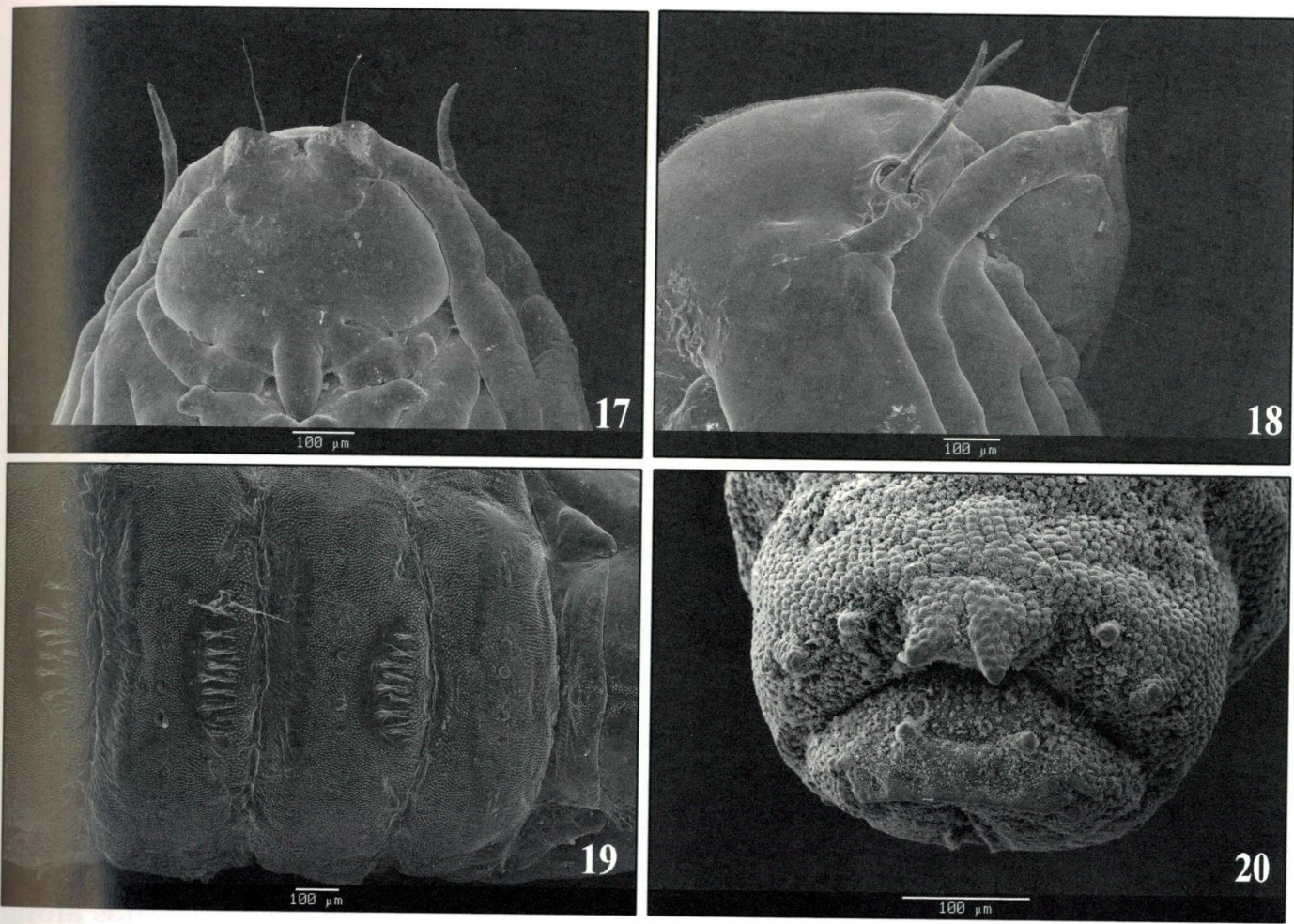

Figs. 17-20. Schizomyia loroco. 17, Pupal anterior segments (ventral). 18, Same (lateral). 19, Pupal scutellum through fourth abdominal segment (dorsal). 20, Larval eighth and terminal segments (dorsoposterior).

length of seventh sternite; cerci separate for at least distal two-thirds with setae at midlength, at two-thirds length, and at apex.

Pupa (Figs. 17-19).-Base of antenna obtusely triangular at apex in ventral view, carinate in lateral view. Cephalic pair of setae nearly twice as long as distance between them. Frons smooth with pair of setae anterior to labrum. Prothoracic spiracle elongate. Second to eighth abdominal segments each with anterodorsal field of several large spines.

Larva.-Third instar (Figs. 13-14, 20): Bright orange in life, elongate, cylindrical, tapered anteriorly, broadly rounded posteriorly. Integument completely verrucose. Spatula robust, with pair of pointed anterior lobes. Papillar pattern typical of supertribe Cecidomyiidi and Schizomyia (Gagné 1994).
Lateral papillae in 2 triplets on each side of spatula, each triplet with 2 setose papillae and 1 asetose papilla. Eighth abdominal segment with two pairs of lobes, medial pair conical and bearing dorsal pair of papillae ventrolaterally, the other pair less prominent, situated between pleural papillae on each side. Terminal segment with papillae as follows: one pair recurved, corniform, but diminutive; one pair with short setae situated below medial lobes of previous segment; two pairs with setae shorter, no longer than wide, one pair situated between corniform papillae, other pair laterad of corniform papillae.

Holotype.-Male, from larva in flower galls of Fernaldia pandurata, Chalatenango, Nueva Concepción, El Salvador, from larva collected VIII-23-2006, emerged IX-16-2006, R. Arce, M. Cas- 
tellón, \& J. Martinez, deposited in the National Museum of Natural History in Washington, DC (USNM).

Other material examined.-3 5, 4 ㅇ, same pertinent data as holotype; 7 larvae, same pertinent data as holotype, collected IX-6-2006; 1 f , 1 ㅇ, Valle de Zapotitán, La Libertad, El Salvador, from larvae collected VII-12-2006, emerged VIII-2-2006, R. Arce, M. Castellón, \& J. Martinez. All deposited in USNM.

Etymology.-The specific name is a noun in apposition and the common name of the host plant.

Remarks.- The new species is the first Schizomyia recorded from Apocynaceae. Twenty-one species of this genus were previously known from the Western Hemisphere. They are listed with their hosts in Gagné (2004), except for the recently described Schizomyia microcapillata Maia from Bauhinea brevipes (Maia \& Fernandes 2005). Based on features of the acropods, these species can be divided into two groups, one of 10 , the other of 11 . In the first group the tarsal claws are hooklike and the empodia nearly as long as the claws (as in Fig. 6); in the second group, to which $S$. loroco belongs, the claws are falcate and the empodia no more than one-third the length of the claws (as in Fig. 5). This latter group also includes Schizomyia caryaecola Felt, Schizomyia eupatoriflorae (Felt), Schizomyia impatientis (Osten Sacken), Schizomyia manihoti Tavares, Schizomyia racemicola (Osten Sacken), Schizomyia rivinae Felt, Schizomyia rubi Felt, Schizomyia speciosa Felt, Schizomyia viticola (Osten Sacken), Schizomyia vitiscoryloides (Packard), and Schizomyia vitispomum (Osten Sacken). Only two of these 11 species, $S$. impatientis and $S$. rivinae, have light and dark-banded flagellomeres similar to $S$. loroco (Fig. 2). Possibly S. manihoti also has banded flagellomeres, but Tavares (1925) wrote that he did not describe the color of his specimens because they had been stored in alcohol. Nevertheless the flagellomere banding, where it exists, is usually retained in alcohol-stored specimens. It is obvious in cleared, slidemounted specimens of the other three species, so Tavares would probably have noticed it had it been there. For present purposes, we suppose that the flagellomeres of S. manihoti are unbanded.

Schizomyia rivinae is known from only one specimen, a female, and the tip of its ovipositor is lost. Its abdomen differs from that of the other two species only in having two complete rows of posterior setae on the seventh tergite rather than one complete row (as in Fig. 9). No differences are apparent between females of $S$. impatientis and those of $S$. loroco. The male is distinguishable in these two species only from the shape of the gonostylus that in $S$. loroco has a narrower apical tooth (Figs. 10-11). The tooth of $S$. impatientis extends along the full width of the gonostylus.

Larvae of Schizomyia offer more effective distinguishing characters than adults, chiefly in the makeup of the eighth and terminal abdominal segments. Larvae of $S$. loroco differ from those of both S. eupatoriflorae and S. impatientis in having pointed instead of rounded lobes between the spiracles of the eighth segment and in having an additional pair of lobes on the eighth segment just laterad of the spiracles and between the lateral pairs of pleural papillae (Figs. 14, 20). In addition, the corniform papillae on the terminal segment are much more diminutive in $S$. loroco than in the other two species (Figs. 15-16), no longer than the hind spiracles and not so conspicuously recurved. The eighth segment lobes of $S$. impatientis are not so deeply divided as in the other two species, and those of $S$. eupatoriflorae are deeply divided but not so pointed as in $S$ loroco.

Ideally, collections of new Schizomyia should include for comparative purposes 
pinned adults with vestiture intact and slide mounted larvae, pupae, and both sexes. Specimens destined for slide mounting can be kept in $70 \%$ ETOH. To obtain the holomorph, of course, requires knowledge of the host plant. Only then is it possible to compare species properly, which one needs to do when describing new species. It is, of course, fortunate that in recent years no one has described any species of this genus from only trap- or net-caught specimens.

\section{Acknowledgments}

We are grateful to Nit Malikul, Systematic Entomology Laboratory (SEL), for preparing the microscopic slides; Marie Metz for arranging the drawings and photos onto plates; John Plakidas, Pittsburgh, PA, for kindly supplying an adult of $S$. eupatoriflorae, a species previously known only from its larval stage; and for their helpful comments on drafts of the manuscript: Keith M. Harris, Woking, Surrey, United Kingdom; Stuart H. McKamey and Allen L. Norrbom, Systematic Entomol- ogy Laboratory; John Plakidas, Pittsburgh, PA; and Makoto Tokuda, Institute for Biological Resources and Functions, Tsukuba City, Japan.

\section{Literature Cited}

Anonymous. 2002. El Cultivo de Loroco (Fernaldia pandurata) en El Salvador. Manual Técnico. Organismo Internacional Regional de Sanidad Agropecuaria - OIRSA. $35 \mathrm{pp}$.

Gagné, R. J. 1989. The Plant-Feeding Gall Midges of North America. Cornell University Press, Ithaca, New York. xi +356 pp., 4 pls.

- 1994. The Gall Midges of the Neotropical Region. Cornell University Press, Ithaca, New York. $\mathrm{xv}+352 \mathrm{pp}$.

C. 2004. A catalog of the Cecidomyiidae (Diptera) of the world. Memoirs of the Entomological Society of Washington No. 23. 408 pp.

McAlpine, J. F., B. V. Peterson, G. E. Shewell, H. J. Teskey, J. R. Vockeroth, and D. M. Wood, eds. 1981. Manual of Nearctic Diptera. Vol. 1. Research Branch, Agriculture, -Canada Monograph No 27. vi +674 pp.

Maia, V. C. and G. Wilson Fernandes. 2005. Two new species of Asphondyliini (Diptera: Cecidomyiidae) associated with Bauhinea brevipes (Fabaceae). Zootaxa 1091: 27-40.

Tavares, J. S. 1925. Nova contribuïção para o conhecimento da cecidologia brazileira. Brotéria, Série Zoológica 22: 5-48. 